$$
\begin{aligned}
& \text { - Eremp } \\
& \text { Jow } 171995 \\
& \text { OSTI }
\end{aligned}
$$

\title{
Contamination Source Review for Building E5974, Edgewood Area, Aberdeen Proving Ground, Maryland
}

Energy Systems Division

Argonne National Laboratory

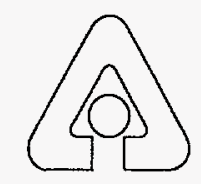

Operated by The University of Chicago, under Contract W-31-109-Eng-38, for the

United States Department of Energy 


\section{Argonne National Laboratory}

Argonne National Laboratory, with facilities in the states of Illinois and Idaho, is owned by the United States Government, and operated by the University of Chicago under the provisions of a contract with the Department of Energy.

This technical memo is a product of Argonne's Energy Systems (ES) Division. For information on the division's scientific and engineering activities, contact:

Director, Energy Systems Division

Argonne National Laboratory

Argonne, Illinois 60439-4815

Telephone (708) 252-3724

Presented in this technical memo are preliminary results of ongoing work or work that is more limited in scope and depth than that described in formal reports issued by the ES Division.

Publishing support services were provided by Argonne's Information and Publishing Division (for more information, see IPD's home page: http://www.ipd.anl.gov/).

\section{Disclaimer}

This report was prepared as an account of work sponsored by an agency of the United States Government. Neither the United States Government nor any agency thereof, nor any of their employees, makes any warranty, express or implied, or assumes any legal liability or responsibility for the accuracy, completeness, or usefulness of any information, apparatus, product, or process disclosed, or represents that its use would not infringe privately owned rights. Reference herein to any specific commercial product, process, or service by trade name, trademark, manufacturer, or otherwise, does not necessarily constitute or imply its endorsement, recommendation, or favoring by the United States Government or any agency thereof. The views and opinions of authors expressed herein do not necessarily state or reflect those of the United States Government or any agency thereof. 


\section{DISCLAMMER}

Portions of this document may be illegible in electronic image products. Images are produced from the best available original document. 


\section{Contamination Source Review for Building E5974, Edgewood Area, Aberdeen Proving Ground, Maryland}

K.A. Billmark, M.E. Emken, D.P. O'Reilly, M.P. Smits, A.K. Draugelis,

J. Rueda, and R.E. Zimmerman

Center for Environmental Restoration Systems, Energy Systems Division,

Argonne National Laboratory, 9700 South Cass Avenue, Argonne, Illinois 60439

\section{Published as}

Contamination Source Review

Edgewood Area, Aberdeen Proving

Ground, Maryland -

Building E5974

September 1995

Work sponsored by United States Department of Defense, United States Army, Aberdeen Proving Ground, Maryland 
बत्

This report is printed on recycled paper. 


\section{Contents}

Summary

1 Introduction.

2 Methodology.

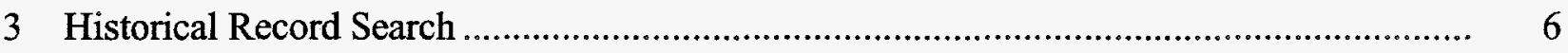

4 Building Description ................................................................................................

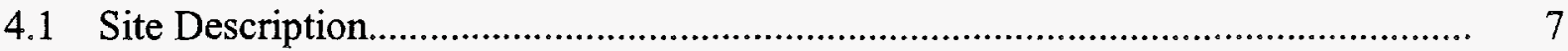

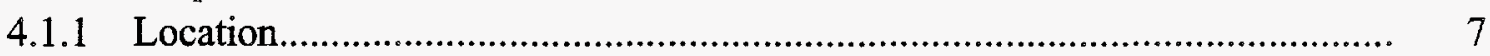

4.1.2 Proximity to Other Buildings ...................................................................... 7

4.1.3 Building Structure................................................................................... 7

4.1.4 Exterior Dimensions ........................................................................... 11

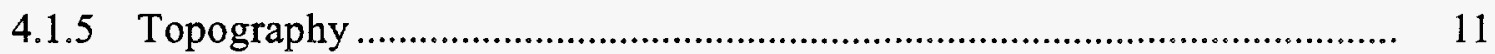

4.1.6 Vegetation in the Immediate Vicinity ......................................................... 11

4.1.7 External Aboveground Structures or Equipment......................................... 11

4.1.8 Connections with Adjacent Buildings ........................................................... 11

4.1.9 Underground Structures ...................................................................... 11

4.1.10 Surface Drainage System ................................................................... 12

4.1.11 Utility Access Points......................................................................... 12

4.1.12 Exterior Piping................................................................................... 12

4.1.13 Nearby Roads and Sidewalks ........................................................... 12

4.2 North Exterior Elevation .................................................................................. 12

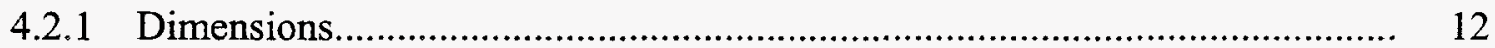

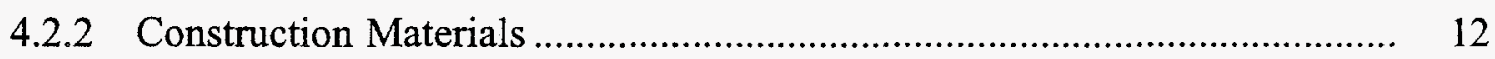

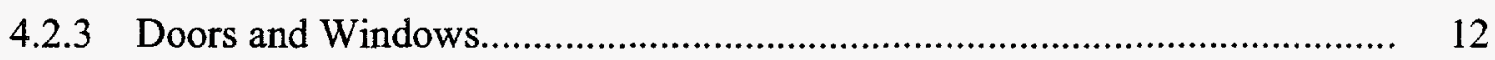

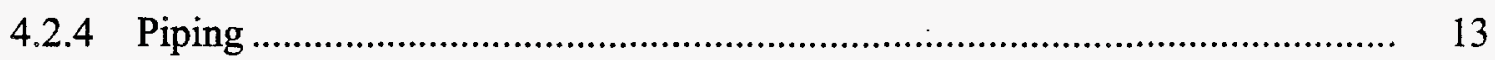

4.2.5 Utility Connections........................................................................... 13

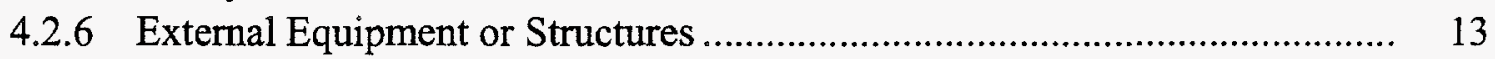

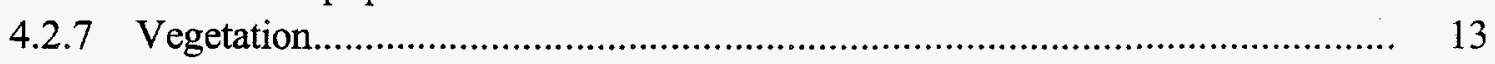

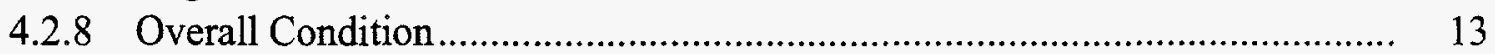

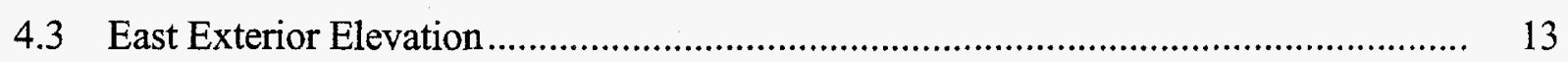

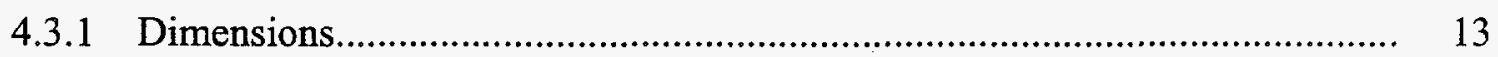

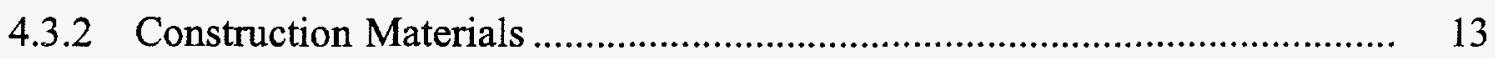

4.3.3 Doors and Windows........................................................................ 14

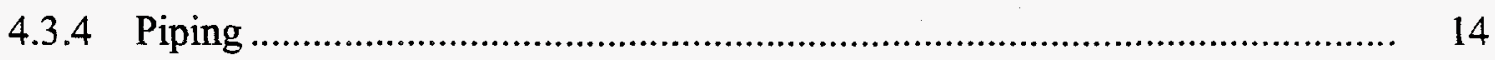

4.3.5 Utility Connections....................................................................... 14

4.3.6 External Equipment or Structures ……................................................. 14

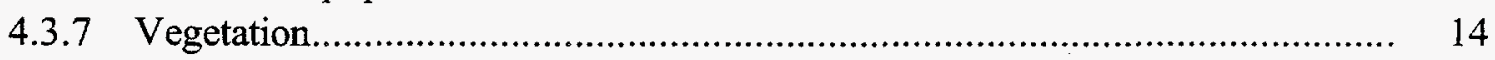

4.3.8 Overall Condition .............................................................................. 


\section{Contents (Cont.)}

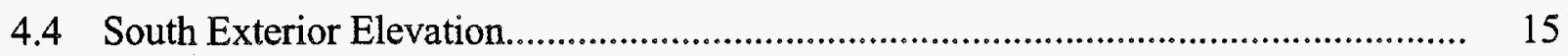

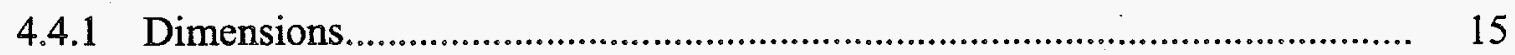

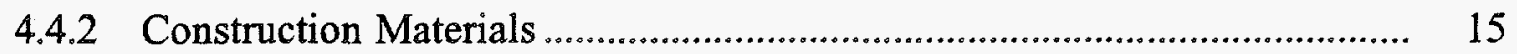

4.4.3 Doors and Windows.............................................................................. 15

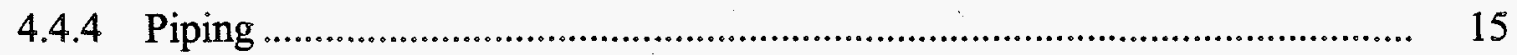

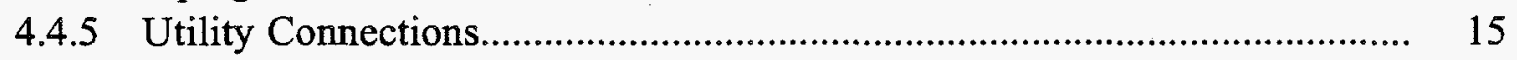

4.4.6 External Equipment or Structures ………………...................................... 15

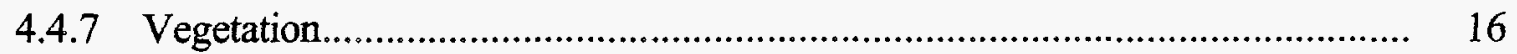

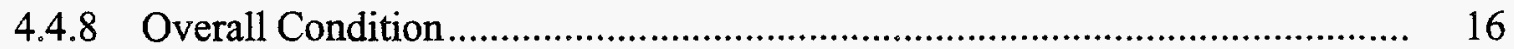

4.5 West Exterior Elevation................................................................................... 16

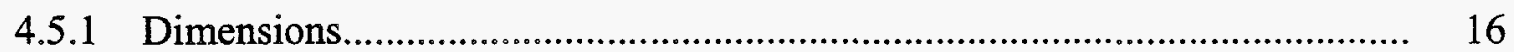

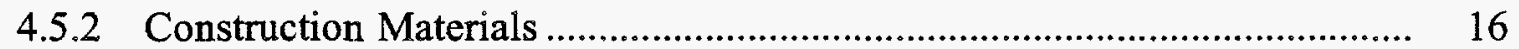

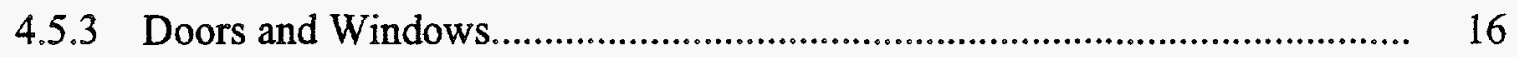

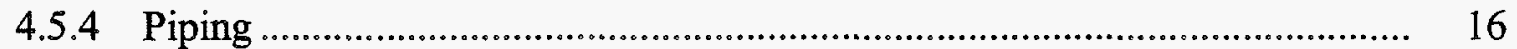

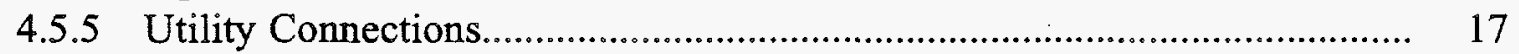

4.5.6 External Equipment or Structures ............................................................. 17

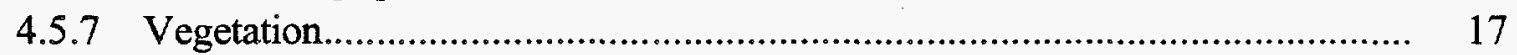

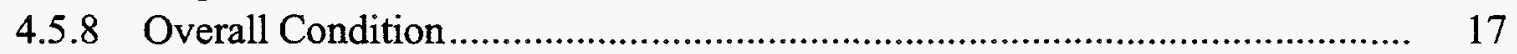

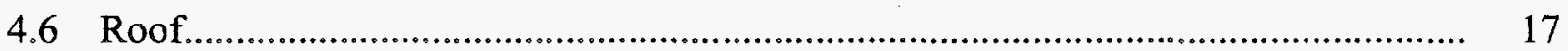

4.6.1 Type and Dimensions ............................................................................. 17

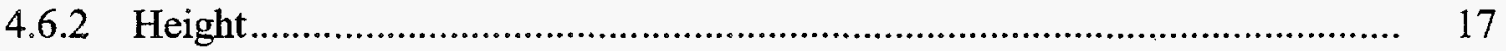

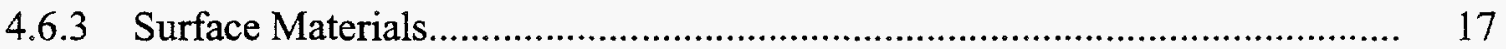

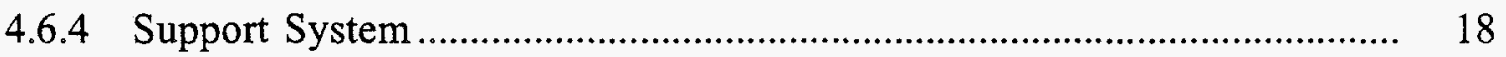

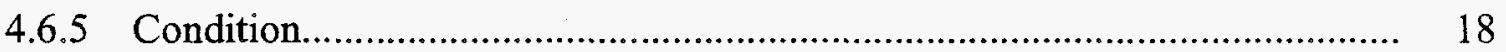

4.6.6 Equipment Located on the Roof ........................................................... 18

4.6.7 Chimneys, Roof Vents, or Vent Stacks.................................................... 18

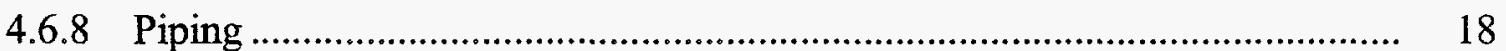

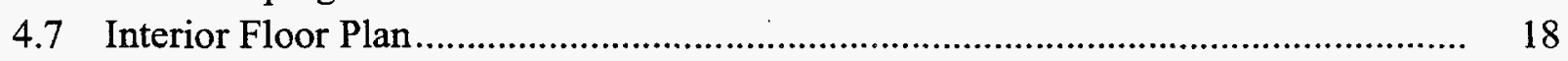

4.7.1 Room Numbers and Dimensions........................................................... 18

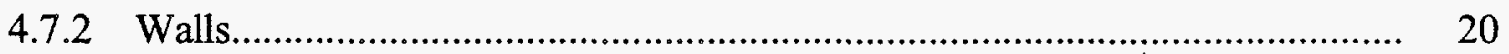

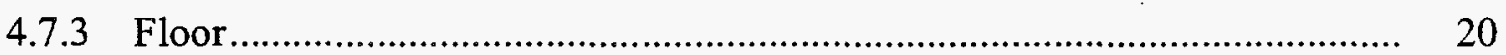

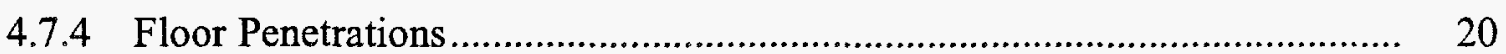

4.7.5 Interior Partitions ................................................................................ 20

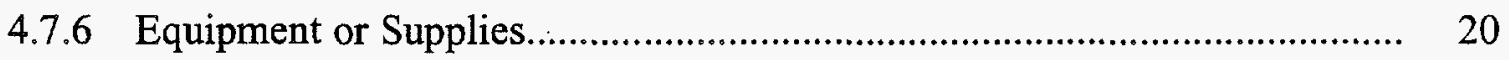

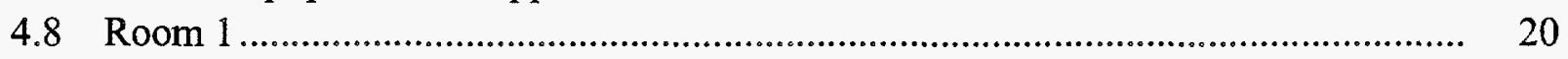

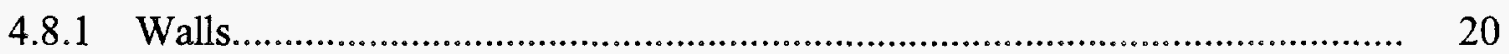

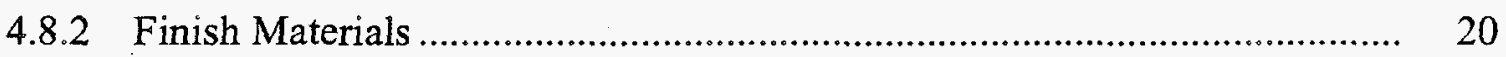

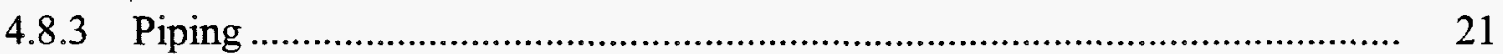

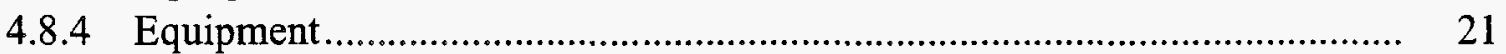

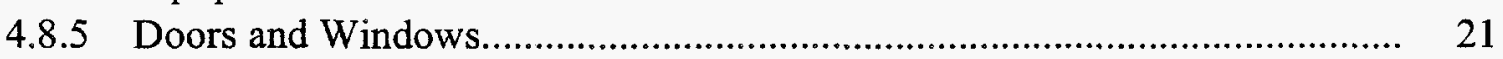

4.8.6 Ceiling and Floor …............................................................................. 21 


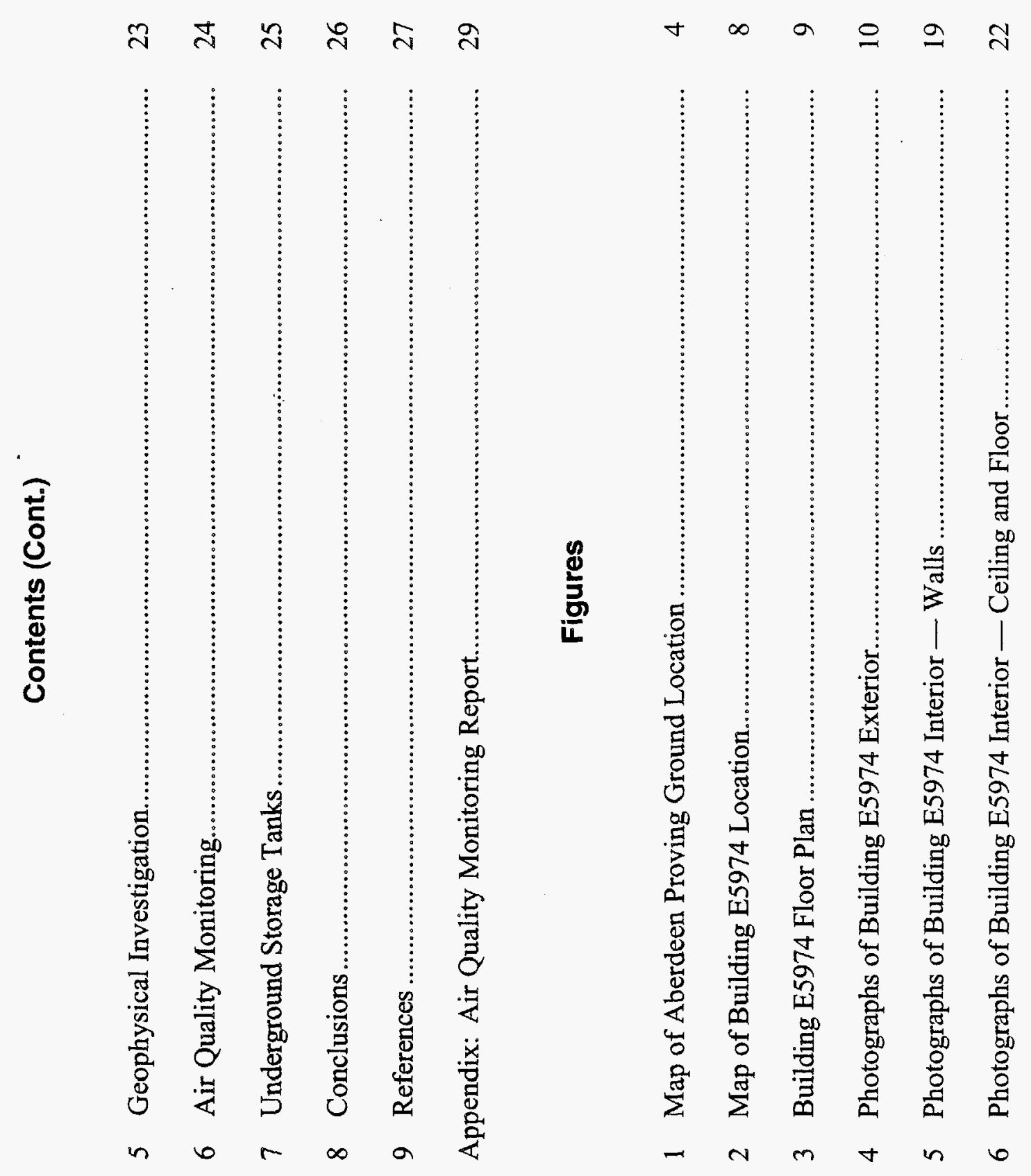




\title{
Contamination Source Review for Building E5974, Edgewood Area, Aberdeen Proving Ground, Maryland
}

\author{
by \\ K.A. Billmark, M.E. Emken, \\ D.P. O'Reilly, M.P. Smits, A.K. Draugelis, \\ J. Rueda, and R.E. Zimmerman
}

\section{Summary}

This report was prepared by Argonne National Laboratory (ANL) to document the results of a contamination source review of Building E5974 at the Aberdeen Proving Ground (APG) in Maryland. The report may be used to assist the U.S. Army in planning for the future use or disposition of this building. The review included a historical records search, physical inspection, photographic documentation, geophysical investigation, and collection of air samples. The field investigations were performed by ANL during 1994 and 1995.

Building E5974 (APG designation) is located on Hog Point Road near the Gunpowder River in the Edgewood Area of APG. Building E5974 was used from 1960 through 1976 as a field office. The building was placed on inactive status in 1976.

The physical inspection and photographic documentation of Building E5974 were completed in November 1994. Building E5974 is a single-story, square structure containing one room. The $16 \mathrm{ft} 6 \mathrm{in}$. by $16 \mathrm{ft} 6 \mathrm{in}$. building is of wood-frame construction with a gable roof covered by asphalt shingles. Exterior walls consist of horizontal planking covered with transite siding. The building has been reroofed; the original roof was most likely covered by the present roof. The building has a wood floor over wooden framing that is most likely supported by concrete blocks or pier stones. The building has no apparent foundation. The interior walls and ceiling are finished with plywood sheeting. The building interior appeared to have been vandalized; some of the plywood sheeting had been removed and portions of the interior floor had been burned. No evidence of plumbing, heating, or electrical connections or floor drains was observed inside the building during ANL's inspection.

In April and May 1992, ANL staff conducted geophysical surveys in the immediate vicinity of Building E5974 by using several nonintrusive methods. Survey results suggest the presence of some underground objects near Building E5974 but do not provide conclusive evidence of the source of geophysical anomalies observed during the survey.

Air quality samples were collected upwind, downwind, and inside Building E5974 in November 1994. Analytical results showed no distinguishable difference in the levels of hydrocarbons and chlorinated solvents between the two background samples and the sample 
collected inside the building. These air quality monitoring results indicate that Building E5974 is not a source of volatile organic compound contamination.

No information on underground storage tanks associated with. Building E5974 was available.

On the basis of information collected and reviewed for Building E5974, it is the authors' judgment that no significant air contamination is associated with this building. The geophysical surveys indicate some anomalies in the vicinity of Building E5974 that warrant further investigation and evaluation. 


\section{Introduction}

The U.S. Army Aberdeen Proving Ground (APG) commissioned Argonne National Laboratory (ANL) to conduct a contamination source review to identify and define areas of toxic or hazardous contaminants and to assess the physical condition and accessibility of APG buildings. The information obtained from this review may be used to assist the U.S. Army in planning for the future use or disposition of the buildings. The contamination source review consisted of the following tasks: historical records search, physical inspection, photographic documentation, geophysical investigation, and collection of air samples. This report provides the results of the contamination source review for Building E5974.

Located on Chesapeake Bay in Harford and Baltimore counties, Maryland, APG occupies approximately 30,000 acres. The facility is divided into the Aberdeen and Edgewood areas (Figure 1). The primary mission at APG has been the testing and evaluation of U.S. Army warfare materials. Since its beginning in 1917, the Edgewood Area of APG has been the principal location for chemical warfare agent research, development, and testing in the United States. APG was also used for producing chemical warfare agents during both world wars, and it has been a center for the storage of chemical warfare material (Nemeth 1989).

Many of the APG facilities constructed between 1917 and the 1960s are no longer used because of obsolescence and their poor state of repair. Because many of these buildings were used for research, development, testing, and/or pilot-scale production of chemical warfare agents and other military substances (such as incendiary materials or munitions containing these materials), the potential exists for portions of the buildings to be contaminated with these substances, their degradation products, and other laboratory or industrial chemicals. These buildings, and associated structures or appurtenances (e.g., underground or aboveground storage tanks, pipes, sumps), may contribute to environmental concerns at APG. 


\section{PENNSYLVANIA}

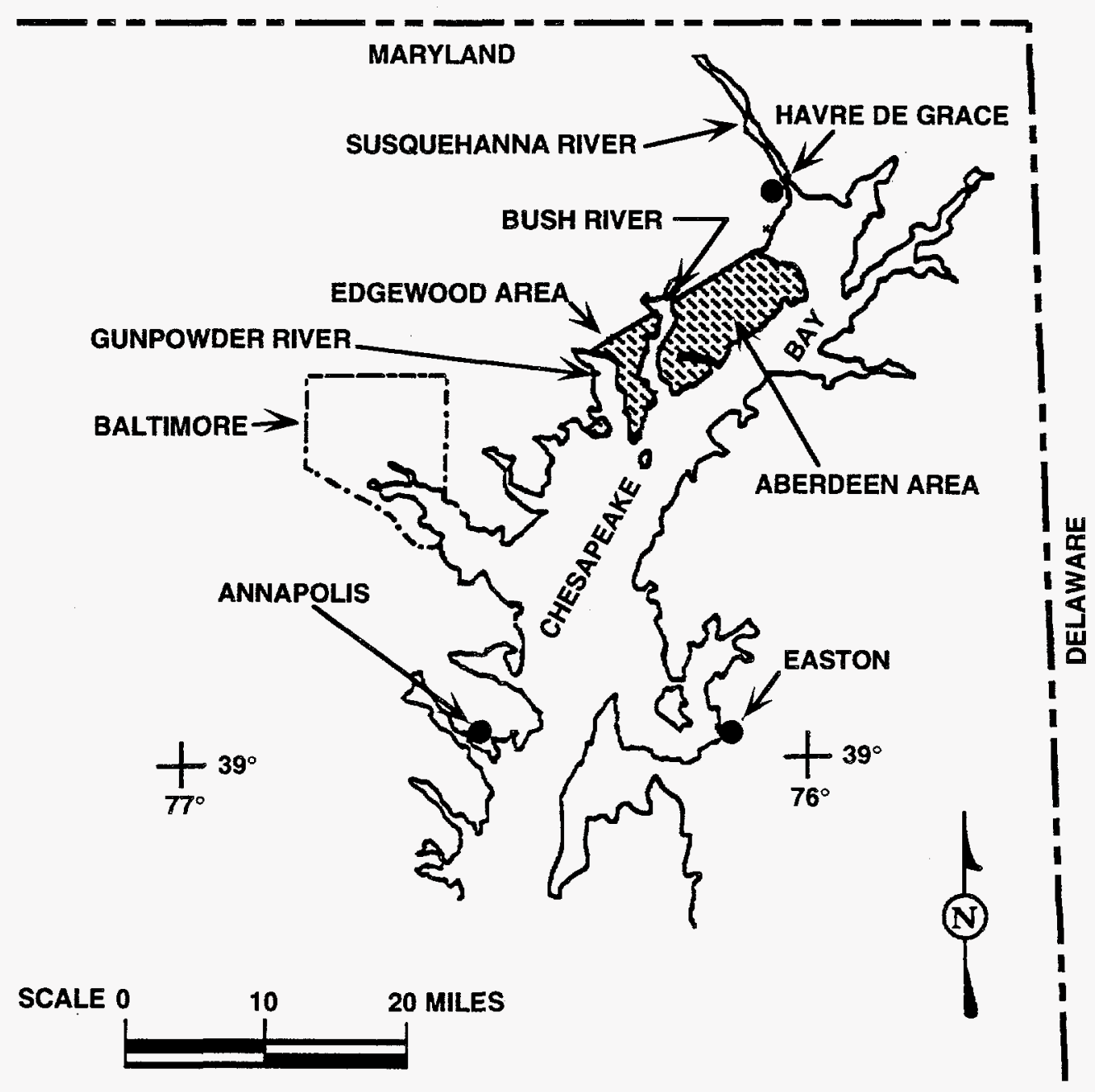

SHADED AREA INDICATES ABERDEEN PROVING GROUND

FIGURE 1 Map of Aberdeen Proving Ground Location 


\section{Methodology}

Before the detailed building inspection, ANL personnel made a preliminary site visit to locate the building and obtain building records from APG, identify potential issues to be addressed in the health and safety plan, resolve any access restriction issues, and identify required support services.

Photographs were taken of the building's exterior and interior surfaces during the building inspection in November 1994. The photographs followed a set sequence whenever possible. The exterior was photographed starting on the north side and continuing clockwise around the building; walls were photographed starting in the north or northwest corner of each room and continuing clockwise until reaching the starting point. The ceiling and floor of each room were also photographed.

The area around Building E5974 was examined in April and May 1992 by using several nonintrusive geophysical survey methods, including total field magnetics, electrical conductivity (EM-31), and ground-penetrating radar (GPR).

ANL staff collected air quality samples upwind, downwind, and inside of Building E5974 during November 1994. Organic compounds trapped from 24-liter samples passed through a sorbent polymer cartridge were analyzed by using a gas chromatograph equipped with a mass spectrometer. Compound identification was based on mass spectral interpretation and a computer search of the 140,000 compounds in the Wiley spectral library.

Detailed descriptions of the methodologies used for the air quality monitoring are provided in the appendix to this report. 


\section{Historical Record Search}

Building E5974 is located on Hog Point Road near the Gunpowder River in the Edgewood Area of APG. The building, constructed in 1960 (EAI Corporation 1989), was heated and served primarily as a field office during training and testing. Building E5974 was placed on inactive status in 1976 (EAI Corporation 1989). 


\section{Building Description}

This section presents a physical description of Building E5974 and the surrounding area as they appeared during ANL's 1994 inspection. The physical description includes an account of the condition of the exterior walls, roof, ceiling, and floor of the building. There was no evidence of plumbing, heating, or electrical connections or floor drains inside the building during the ANL inspection.

\subsection{Site Description}

\subsubsection{Location}

Building E5974 is located on Hogs Point Road in the Westwood section of APG's Edgewood Area. Major geographic features in the general vicinity of Building E5974 include Hog Point, Reardon Inlet (a small stream), and the Gunpowder River (Figure 2).

\subsubsection{Proximity to Other Buildings}

Building E5974 is located approximately $50 \mathrm{ft}$ to the west of Building E5978. Both of these buildings are in the isolated Westwood section of APG.

\subsubsection{Building Structure}

Building E5974 is a single-room, single-story, square structure oriented north to south. The exterior walls of the building consist of vertical wood framing and horizontal planking covered with transite siding. The building is constructed with a simple gable roof covered by asphalt shingles. The building has been reroofed; the present roof most likely covers the original roof. The floor of Building E5974 is wood planking over a wood frame that is most likely supported by concrete blocks or pier stones. There is no evidence of a foundation for Building E5974. The interior walls and ceiling are finished with plywood sheeting. The interior of the building appeared to have been vandalized; some of the interior plywood had been removed and portions of the interior floor had been burned. Figure 3 presents a floor plan of the building, developed from the ANL survey and historical documentation (EAI Corporation 1989). Figure 4 provides photographs of the exterior of the building. 


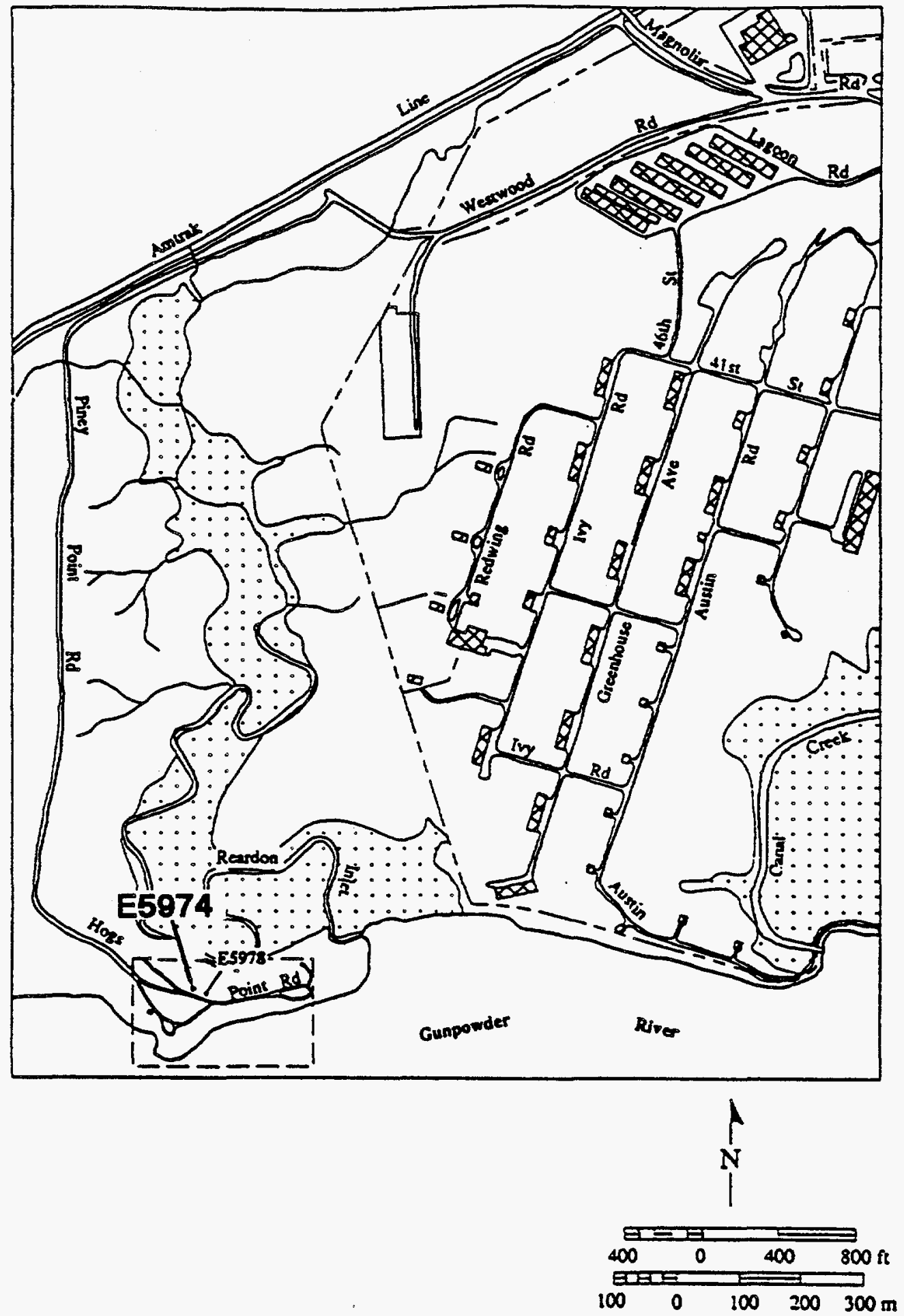

FIGURE 2 Map of Building E5974 Location 


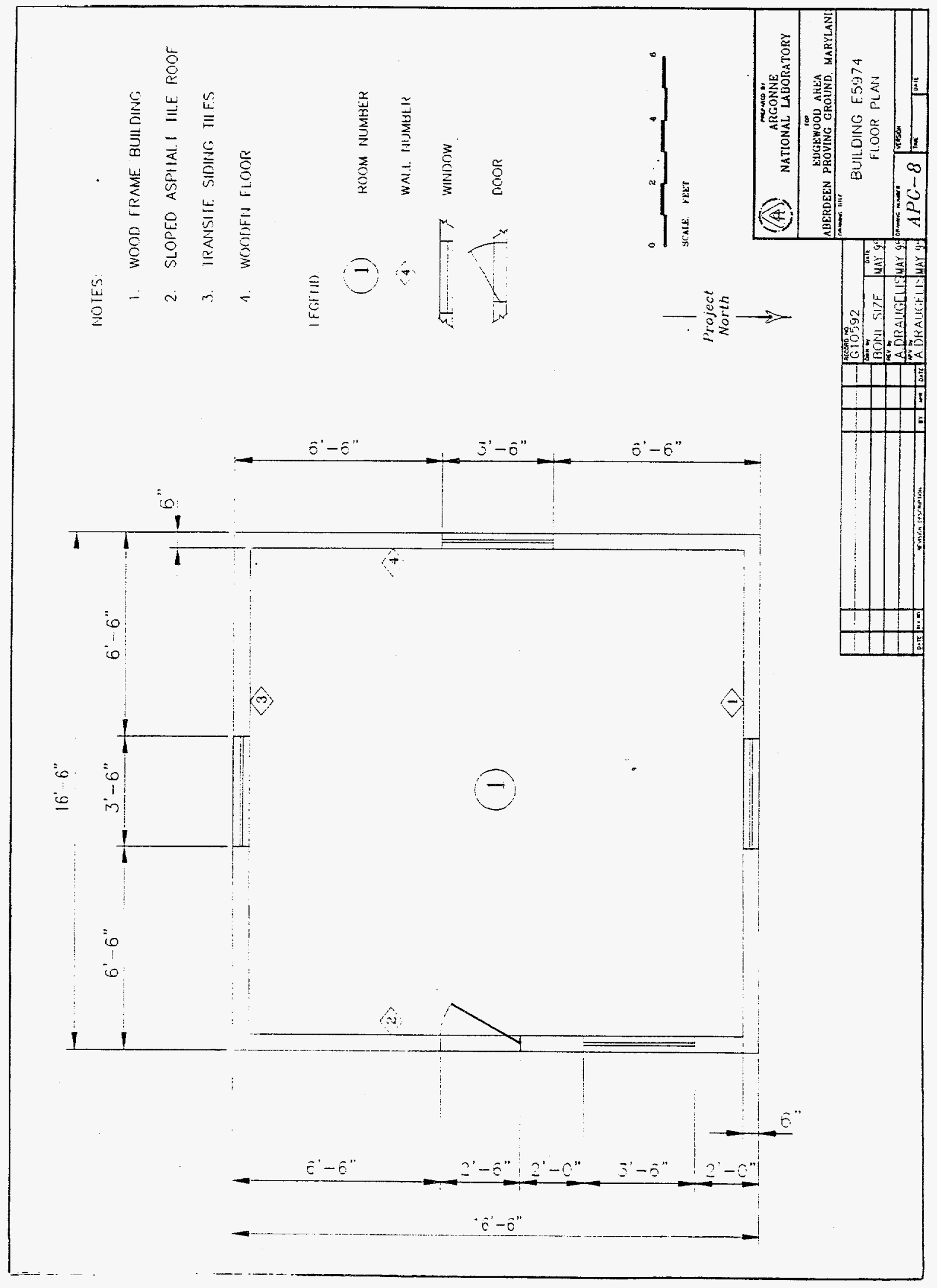

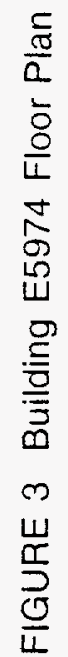



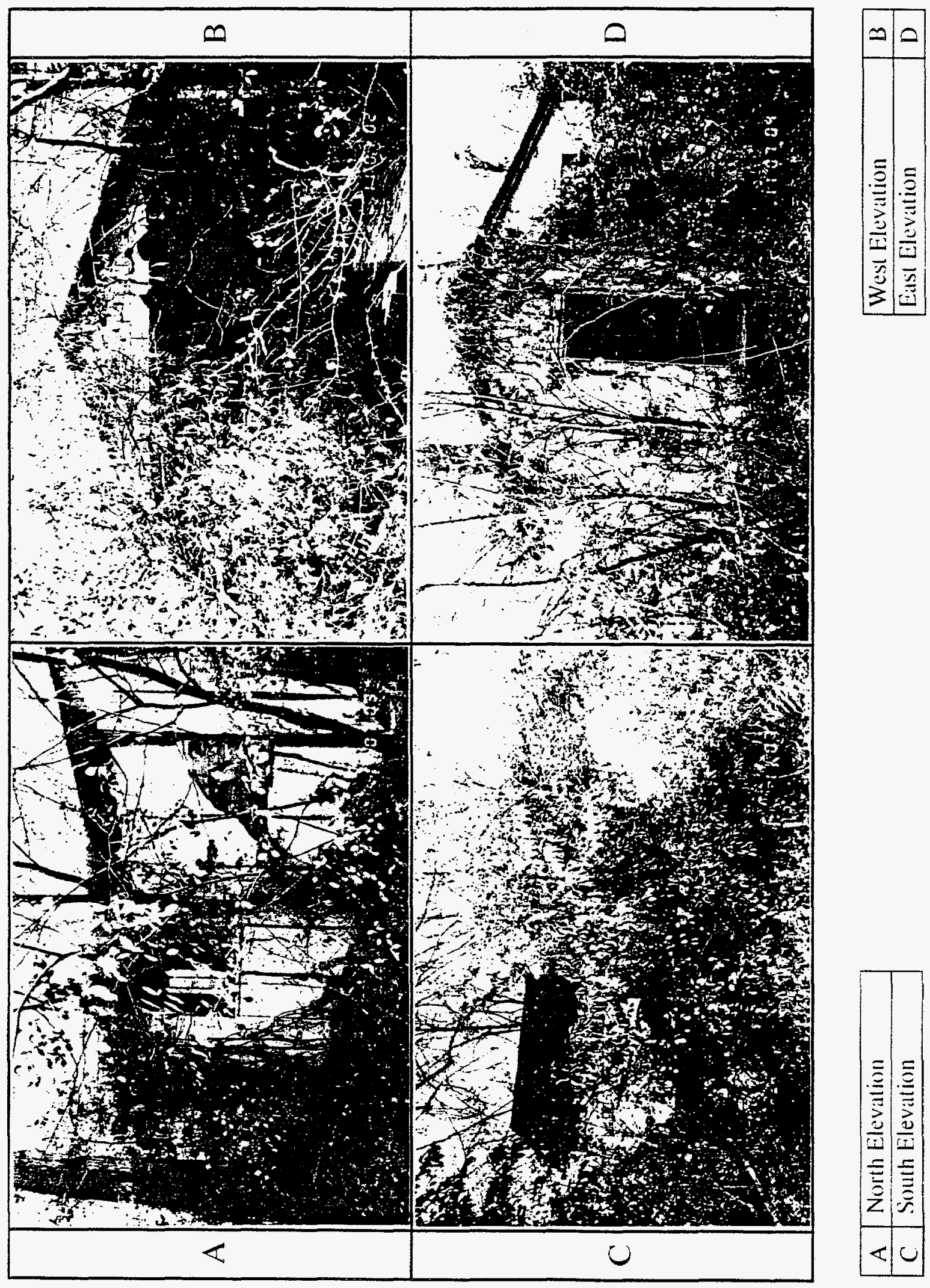

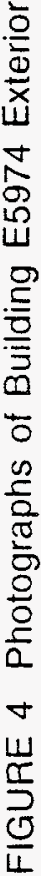




\subsubsection{Exterior Dimensions}

The exterior dimensions of Building E5974 are $16 \mathrm{ft} 6$ in. by $16 \mathrm{ft} 6$ in. (Figure 3). The height of the eaves is about $8 \mathrm{ft}$ and the height at the peak of the gable is about $12 \mathrm{ft}$.

\subsubsection{Topography}

Building E5974 is located in an area of APG known as Hog Point. This area is approximately .25 mile wide and extends approximately .5 mile east to west. It is bordered to the south by the Gunpowder River and to the north by a low swamp area known as Reardon Inlet. Hog Point itself is relatively flat and very heavily wooded. The site of Building E5974, approximately $100 \mathrm{ft}$ from the Chesapeake Bay, is higher than most of the surrounding ground.

\subsubsection{Vegetation in the Immediate Vicinity}

The area directly surrounding Building E5974 is densely vegetated. Small trees are growing within $2 \mathrm{ft}$ of the building, and a network of vines has almost entirely covered the structure.

\subsubsection{External Aboveground Structures or Equipment}

Within several feet directly south of Building E5974 is an old fuel oil tank. This tank appears to have been associated with a heating system that once served the building (no longer present); a chimney for this system is still located on the roof of the structure.

\subsubsection{Connections with Adjacent Buildings}

None.

\subsubsection{Underground Structures}

None. 


\subsubsection{Surface Drainage System}

None.

\subsubsection{Utility Access Points}

None.

\subsubsection{Exterior Piping}

None.

\subsubsection{Nearby Roads and Sidewalks}

Hog Point Road is south of Building E5974.

\subsection{North Exterior Elevation}

\subsubsection{Dimensions}

The north exterior wall of Building E5974 is $16 \mathrm{ft} 6 \mathrm{in.} \mathrm{long.} \mathrm{The} \mathrm{height} \mathrm{at} \mathrm{the} \mathrm{eaves} \mathrm{is}$ about $8 \mathrm{ft}$ and at the peak of the roof is about $12 \mathrm{ft}$ (Figure 3).

\subsubsection{Construction Materials}

The north exterior wall of Building E5974 is constructed of vertical wood framing and horizontal planking covered with transite siding.

\subsubsection{Doors and Windows}

One $48 \mathrm{in.} \mathrm{by} 48 \mathrm{in.}$ window opening is located in the approximate center of the north wall of Building E5974. The sash and frame of the window are no longer present, but the opening contains steel security bars. 


\subsubsection{Piping}

None.

\subsubsection{Utility Connections}

None.

\subsubsection{External Equipment or Structures}

None.

\subsubsection{Vegetation}

The area surrounding Building E5974 is covered by dense vegetation. Small trees are abundant near the building, and a network of vines has almost entirely covered the structure.

\subsubsection{Overall Condition}

Because of a lack of maintenance, Building E5974 shows signs of severe deterioration and weathering.

\subsection{East Exterior Elevation}

\subsubsection{Dimensions}

The east exterior wall of Building E5974 measures $16 \mathrm{ft} 6 \mathrm{in.}$ long; the height of the eaves is about $8 \mathrm{ft}$, and the height at the peak of the gable is about $12 \mathrm{ft}$ (Figure 3 ).

\subsubsection{Construction Materials}

The exterior walls of the building consist of vertical wood framing and horizontal planking covered with transite siding. 


\subsubsection{Doors and Windows}

The only entrance to the building is located on the east elevation. This door opening measures $32 \mathrm{in}$. wide by $82 \mathrm{in}$. high. The door is no longer present. A window opening that measures $48 \mathrm{in}$. by $48 \mathrm{in}$. is located $16 \mathrm{in}$. to the north of this door. The sash and frame of the window are no longer present, but the opening contains steel security bars.

\subsubsection{Piping}

None.

\subsubsection{Utility Connections}

None.

\subsubsection{External Equipment or Structures}

None.

\subsubsection{Vegetation}

The area surrounding Building E5974 is densely vegetated. Small trees are abundant near the building, and a network of vines has almost entirely covered the structure.

\subsubsection{Overall Condition}

Because of a lack of maintenance, Building E5974 shows signs of severe deterioration and weathering. 


\subsection{South Exterior Elevation}

\subsubsection{Dimensions}

The south exterior wall of Building E5974 measures $16 \mathrm{ft} 6$ in. long; the height of the eaves is about $8 \mathrm{ft}$ and the height at the peak of the gable is about-12 $\mathrm{ft}$ (Figure 3).

\subsubsection{Construction Materials}

The south exterior wall of the building consists of vertical wood framing and horizontal planking covered with transite siding.

\subsubsection{Doors and Windows}

One window opening measuring $48 \mathrm{in.}$ by $48 \mathrm{in}$. is located in the approximate center of the south exterior wall. The sash and frame of the window are no longer present, but the opening contains steel security bars.

\subsubsection{Piping}

None.

\subsubsection{Utility Connections}

None.

\subsubsection{External Equipment or Structures}

None. 


\subsubsection{Vegetation}

The area surrounding Building E5974 is densely vegetated. Small trees are abundant near the building, and a network of vines has almost covered the entire structure.

\subsubsection{Overall Condition}

Because of a lack of maintenance, Building E5974 shows signs of severe deterioration and weathering.

\subsection{West Exterior Elevation}

\subsubsection{Dimensions}

The west exterior wall of Building E5974 measures $16 \mathrm{ft} 6 \mathrm{in}$. long; the height of the eaves is about $8 \mathrm{ft}$, and the height at the peak of the gable is about $12 \mathrm{ft}$ (Figure 3).

\subsubsection{Construction Materials}

The west exterior wall of the building consists of vertical wood framing and horizontal planking covered with transite siding.

\subsubsection{Doors and Windows}

One window opening measuring $48 \mathrm{in.} \mathrm{by} 48 \mathrm{in}$. is located in the approximate center of the west exterior wall. The sash and frame of the window are no longer present, but the opening contains steel security bars.

\subsubsection{Piping}

The west exterior wall of Building E5974 contains no piping. Evidence shows that piping did exist at this location at one time. One old 200-gal aboveground fuel tank is located outside Building E5974 near its west side. A chimney is located on the west side of the roof. 


\subsubsection{Utility Connections}

None.

\subsubsection{External Equipment or Structures}

None.

\subsubsection{Vegetation}

The area surrounding Building E5974 is densely vegetated. Small trees are abundant near the building, and a network of vines has almost entirely covered the structure.

\subsubsection{Overall Condition}

Because of a lack of maintenance, Building E5974 shows signs of severe deterioration and weathering.

\subsection{Roof}

\subsubsection{Type and Dimensions}

Building E5974 has a 6/12 gable roof measuring $16 \mathrm{ft} 6$ in. by $16 \mathrm{ft} 6$ in.

\subsubsection{Height}

The height of the roof at the eaves is about $8 \mathrm{ft}$ and at the peak is about $12 \mathrm{ft}$.

\subsubsection{Surface Materials}

The roof of Building E5974 is covered by asphalt shingles. 


\subsubsection{Support System}

The roof is supported by wood rafters.

\subsubsection{Condition}

The roof of Building E5974 appeared to be in fair condition at the time of the inspection.

\subsubsection{Equipment Located on the Roof}

None.

\subsubsection{Chimneys, Roof Vents, or Vent Stacks}

One circular vent stack is located in the southwest corner of the roof. The vent stack is constructed of galvanized round ductwork and is equipped with a conical top for protection from the weather. This vent stack extends approximately $2 \mathrm{ft}$ above the roof surface. This type of chimney was commonly used as an exhaust vent for combustion heaters.

\subsubsection{Piping}

None.

\subsection{Interior Floor Plan}

\subsubsection{Room Numbers and Dimensions}

Building E5974 is a single-story, one-room building. The interior measures $15 \mathrm{ft} 6$ in. by $15 \mathrm{ft} 6$ in. (Figures 3 and 5). 

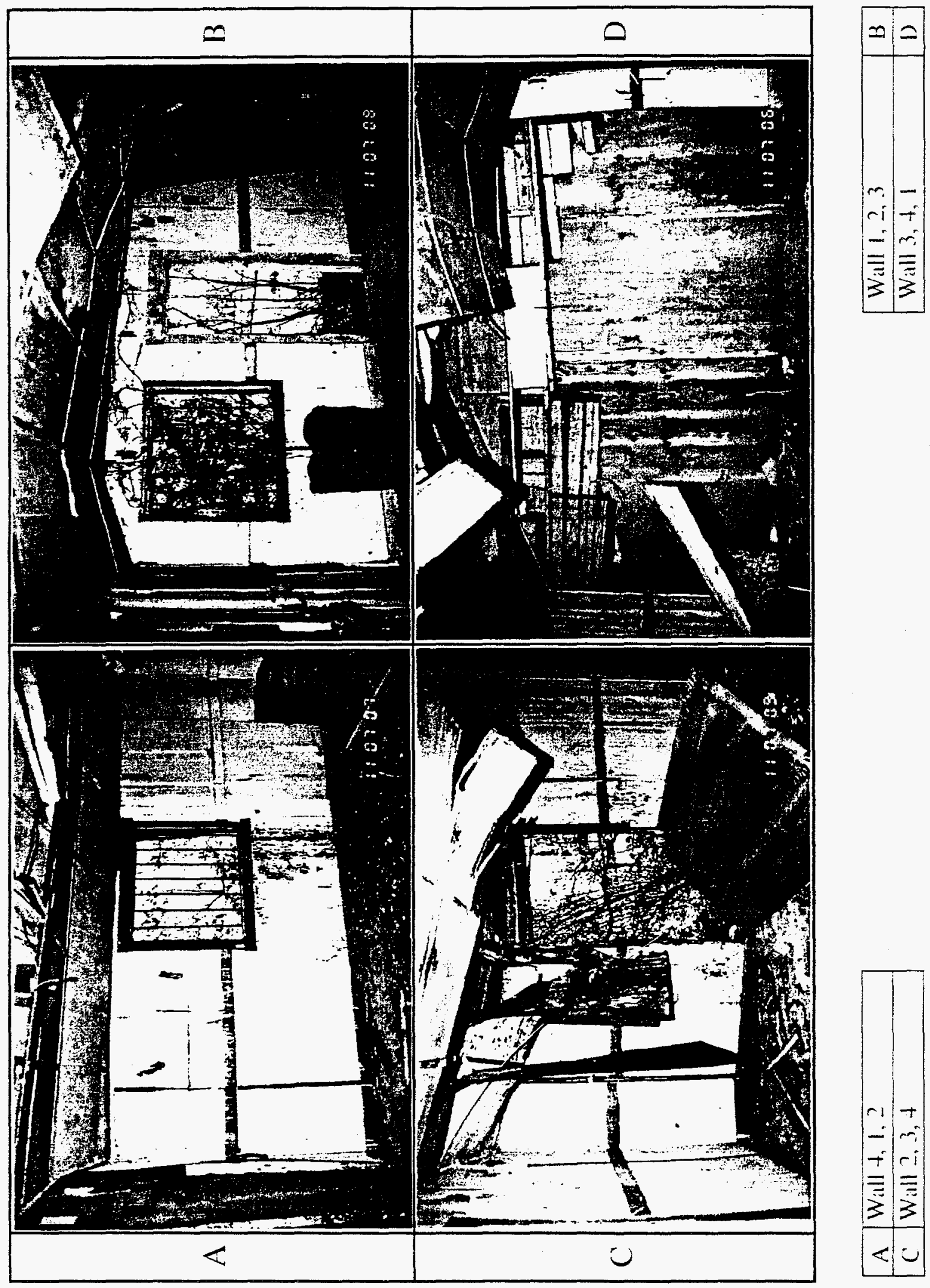

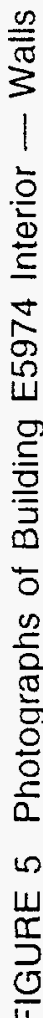




\subsubsection{Walls}

The interior walls are common with the exterior walls and extend from the floor to the roof line of the building.

\subsubsection{Floor}

The floor of Building E5974 is wood planking installed over a wood frame.

\subsubsection{Floor Penetrations}

None.

\subsubsection{Interior Partitions}

None.

\subsubsection{Equipment or Supplies}

None.

\subsection{Room 1}

\subsubsection{Walls}

The interior walls of room 1 are common with the exterior walls and extend from the floor to the roof line of the building.

\subsubsection{Finish Materials}

The interior walls of Building E5974 are finished with plywood sheeting (Figure 5). 


\subsubsection{Piping}

None.

\subsubsection{Equipment}

None.

\subsubsection{Doors and Windows}

There is one 32-in.-wide by 82 -in.-high door opening in the east exterior wall of Building E5974. One 48-in. by 48-in. window opening is located in the approximate center of each of the north, west, and south exterior walls. Another 48 -in. by 48 -in. window opening is located in the east exterior wall 16 in. north of the door. The floor plan of Building E5974 (shown in Figure 3) was developed from measurements taken during the field survey and from historic documentation (EAI Corporation 1989).

\subsubsection{Ceiling and Floor}

The ceiling is finished with plywood sheeting (Figure 6). The floor is wood planking installed over a wood frame. 

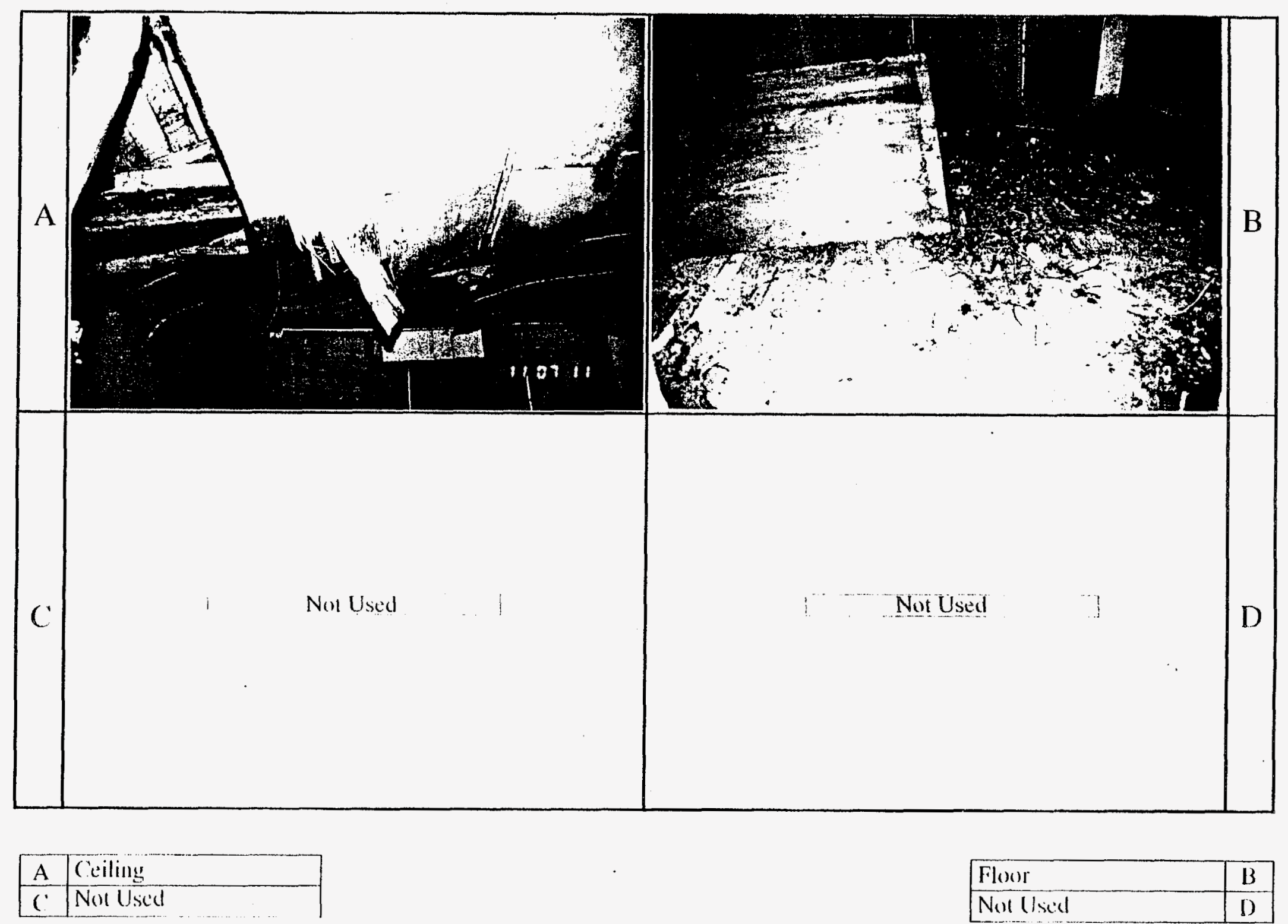

FIGURE 6 Photographs of Building E5974 Interior - Ceiling and Floor 


\section{Geophysical Investigation}

ANL personnel conducted a geophysical survey of the area surrounding Building E5974 in April and May 1992 (McGinnis et al. 1992). Noninvasive geophysical survey methods, including magnetics, electrical resistivity, and GPR were conducted around the building.

The following specific conclusions were drawn from the geophysical surveys of Building E5974 (McGinnis et al. 1992):

- Magnetic anomalies between Buildings E5974 and E5978 and along Hog Point Road are believed to be associated with construction fill and road-grade material.

- Three magnetic anomalies in the high-resistivity northwest quadrant of the survey area are caused by unidentified sources.

- High resistivities in the west/northwest quadrant are believed to be caused by natural sources; however, an electrical depth-sounding station centered in this zone indicates a layer rising to $3,055 \mathrm{ohm}$-meter. A value this high in a wetland environment is not completely understood, but the GPR data indicate that this reflector may be a sand lens. Core samples taken from the northwest quadrant would satisfy questions about the source of this unusual feature.

- There are no magnetic, electrical, or GPR anomalies immediately surrounding the building that suggest the presence of buried pipes, drains, or tanks. 


\section{Air Quality Monitoring}

ANL staff collected air quality samples upwind, downwind, and inside of Building E5974 during November 1994. Analytical results showed no distinguishable differences in the levels of hydrocarbons and chlorinated solvents among the two background samples and the sample taken inside Building E5974. These results indicate that Building E5974 is not a source of volatile organic compound contamination. The air quality monitoring report is presented in the appendix. 


\section{Underground Storage Tanks}

No information on underground storage tanks associated with Building E5974 is available. 


\section{Conclusions}

On the basis of information collected and reviewed by ANL for Building E5974, it is the authors' judgment that no significant air contamination is associated with this building. Results of the geophysical surveys indicate some anomalies in the vicinity of Building E5974 that warrant further investigation and evaluation. 


\section{References}

EAI Corporation, 1989, Historical Records Search and Site Survey of Edgewood Area Buildings - Final Report, prepared for U.S. Army Chemical Research, Development, and Engineering Center, Aberdeen Proving Ground, Maryland, under contract no. DAAIS-87-D0021.

McGinnis, M.G., L.D. McGinnis, S.F. Miller, and M.D. Thompson, 1992, Interim Progress Report - Geophysics: Decommissioning of Buildings E5974 and E5978, Aberdeen Proving Ground, Maryland, ANL/ESD/TM-47, Argonne National Laboratory, Argonne, Ill.

Nemeth, G., 1989, RCRA Facility Assessment Report, Edgewood Area, Aberdeen Proving Ground, Maryland, unnumbered report prepared for Aberdeen Proving Ground, Maryland. 
Appendix:

Air Quality Monitoring Report 


\section{ARGONNE NATIONAL

March 27, 1995

TO: $\quad$ Eric Zimmerman

FROM: John Schneider ò 58

SUBJECT: Building E5974 Air Monitoring for Volatile Organic Compounds Results

Building E5974 at the Aberdeen Proving Ground (APG) was constructed in 1960 for use as a field office during training and testing. The building was placed on an inactive status in 1976.

Air samples were collected and analyzed on-site at APG by ANL during the week of November 14, 1994. Samples were collected by drawing ambient air through a Tenax TA sorbent polymer sampling cartridge ( $4 \mathrm{~mm}$ I.D. $\times 11.5 \mathrm{~cm}$ ) traps at the rate of $200 \mathrm{~mL}$ for 120 minutes, yielding a $24 \mathrm{~L}$ sample volume. The cartridges were analyzed by thermally desorbing the trapped organic compounds with a Dynatherm model 900 ACEM thermal desorption unit on to a Hewlett-Packard 5890 series II gas chromatograph (GC) equipped with a Hewlett-Packard 5972 mass spectrometer (MS) and flame photometric detector (FPD). The FPD is specific for sulfur or phosphorous containing compounds.

The MS was used for detecting and identifying organic compounds desorbed from the Tenax traps. Spectra were obtained by scanning from 45 to 400 atomic mass units at a rate of two scans every second. Identifications were based on mass spectral interpretation and computer searching of the 140,000 compound Wiley spectral library. A standard mixture of volatile organics containing toluene at $200 \mathrm{ng} / \mathrm{uL}$ and other aromatic hydrocarbons, was run daily to assure that the instrument was operating properly. All quantitations are estimates, using the assumption that analyte response factors should be similar to toluene in the standard mixture of volatile organics.

The FPD was used to "screen" for organic compounds containing sulfur or phosphorous atoms. This information was needed because of the history of the APG in the production and storage of CWA (CWA and CWA degradation products contain sulfur and/or phosphorous). This information was also useful in identifying unknown organic compounds.

The majority of the volatile organic compounds found during the ANL air monitoring are commonly found in any building (hydrocarbons and chlorinated solvents). The following compounds were the major components found in the air samples: 


$\begin{array}{llll}\text { Compound } & \text { E5974 } & \text { Upwind } & \text { Downwind } \\ & & & \\ \text { Benzene } & 0.11 \mathrm{ng} / \mathrm{L} & 0.12 \mathrm{ng} / \mathrm{L} & 0.11 \mathrm{ng} / \mathrm{L} \\ \text { Toluene } & 0.16 \mathrm{ng} / \mathrm{L} & 0.16 \mathrm{ng} / \mathrm{L} & 0.14 \mathrm{ng} / \mathrm{L} \\ \text { Ethyl Benzene } & 0.04 \mathrm{ng} / \mathrm{L} & 0.03 \mathrm{ng} / \mathrm{L} & 0.03 \mathrm{ng} / \mathrm{L} \\ \text { Xylene } & 0.07 \mathrm{ng} / \mathrm{L} & 0.08 \mathrm{ng} / \mathrm{L} & 0.07 \mathrm{ng} / \mathrm{L} \\ \text { Alpha Pinene } & 0.14 \mathrm{ng} / \mathrm{L} & 0.19 \mathrm{ng} / \mathrm{L} & 0.21 \mathrm{ng} / \mathrm{L} \\ \text { Benzaldehyde } & 0.28 \mathrm{ng} / \mathrm{L} & 0.32 \mathrm{ng} / \mathrm{L} & 0.25 \mathrm{ng} / \mathrm{L} \\ \text { Phenol } & 0.05 \mathrm{ng} / \mathrm{L} & 0.09 \mathrm{ng} / \mathrm{L} & 0.06 \mathrm{ng} / \mathrm{L} \\ \text { Beta Pinene } & 0.10 \mathrm{ng} / \mathrm{L} & 0.09 \mathrm{ng} / \mathrm{L} & 0.11 \mathrm{ng} / \mathrm{L} \\ \text { Methyl Phenyl Ketone } & 0.18 \mathrm{ng} / \mathrm{L} & 0.23 \mathrm{ng} / \mathrm{L} & 0.12 \mathrm{ng} / \mathrm{L}\end{array}$

Figure 1 is a total ion chromatogram (TIC) of the air sample taken in E5974. Figures 2 and 3 are TICs of the upwind and downwind air samples.

Table 1 is the Air sampling data sheet.

The analysis indicates that Building E5974 is not a source of volatile organic compound contamination.

JFS:lls 
File

Operator

: C: \HPCHEM $\backslash 2 \backslash D A T A \backslash A 284 . D$

Acquired : 20 Nov $94 \quad 10: 45$ am using AcqMethod PILOT

Instrument : 5972 - In

Sample Name: 284(60) E5974 main rm 3:37-5:37 200mL/min

Misc Info : start, $200 \mathrm{~mL} / \mathrm{min}$ end, facing ceiling

Vial Number: 1

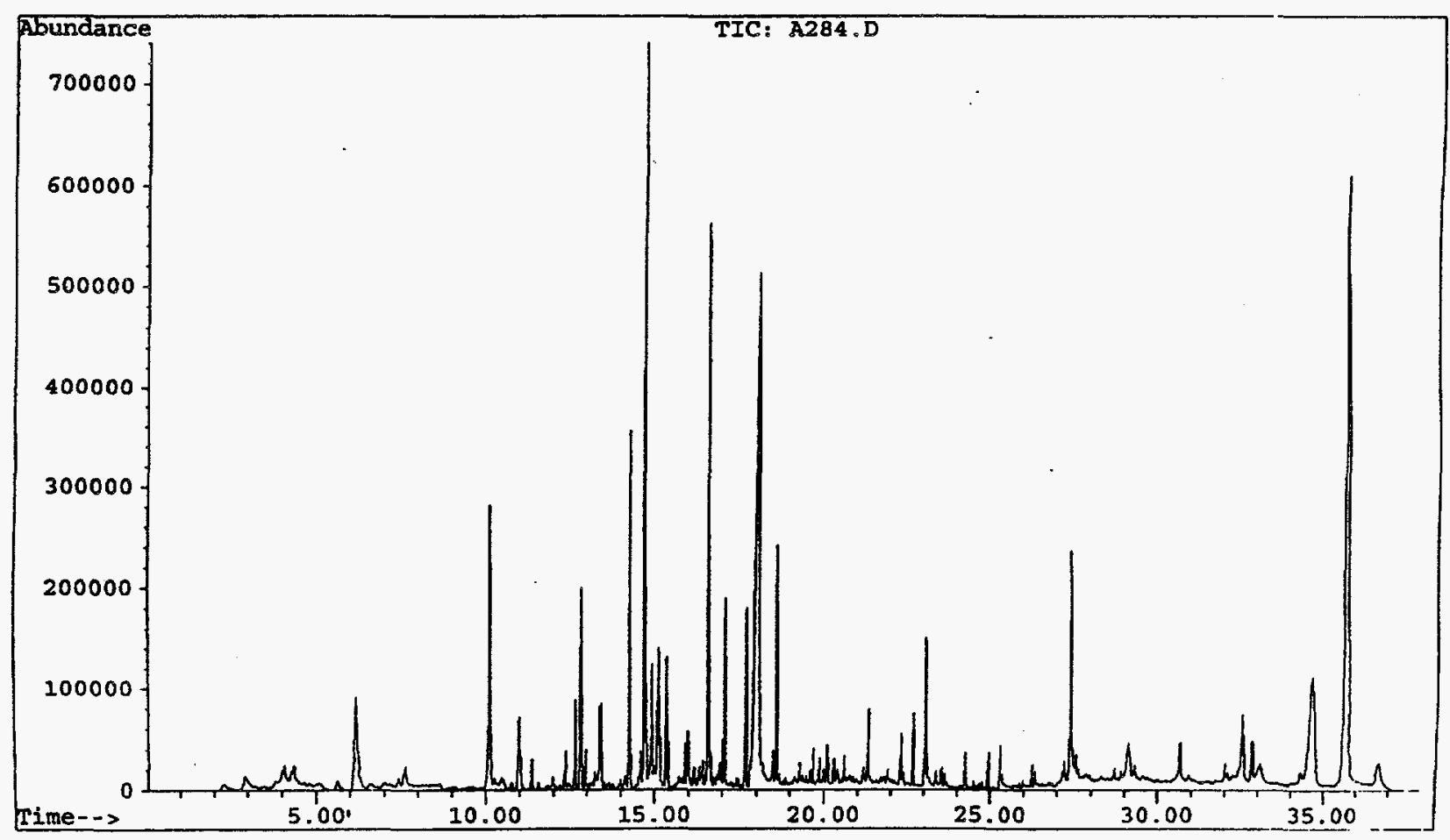


File

: C: \HPCHEM $\backslash 2 \backslash D A T A \backslash A 282 . D$

Operator

lar

Acquired : 20 Nov $94 \quad 11: 33$ am using AcqMethod RIIOT

Instrument : 5972 - In

Sample Name: 282 (53) E5974 upwind 3:33-5:33 200mL/min

Misc Info : start, $200 \mathrm{~mL} / \mathrm{min}$ end, facing north

Vial Number: 1

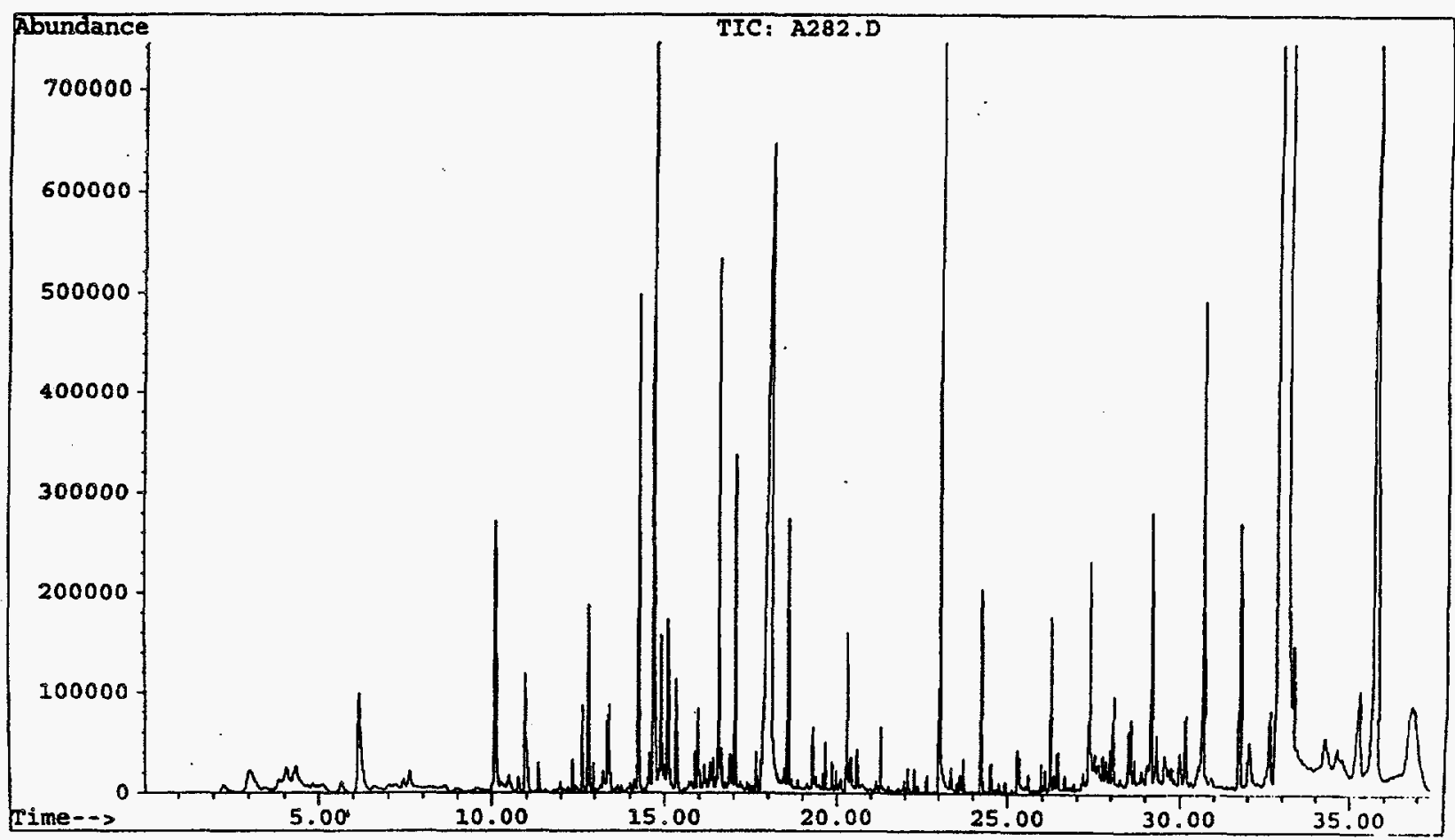


File

: C: \HPCHEM \2\DATA \A283.D

Operator

: lar

Acquired : 20 Nov $9412: 22 \mathrm{pm}$ using AcqMethod PILOT

Instrument : 5972 - In

Sample Name: $283(59)$ E5974 downwind 3:33-5:33 200mL/min

Misc Info : start, $100 \mathrm{~mL} / \mathrm{min}$ end, facing north

Vial Number: 1

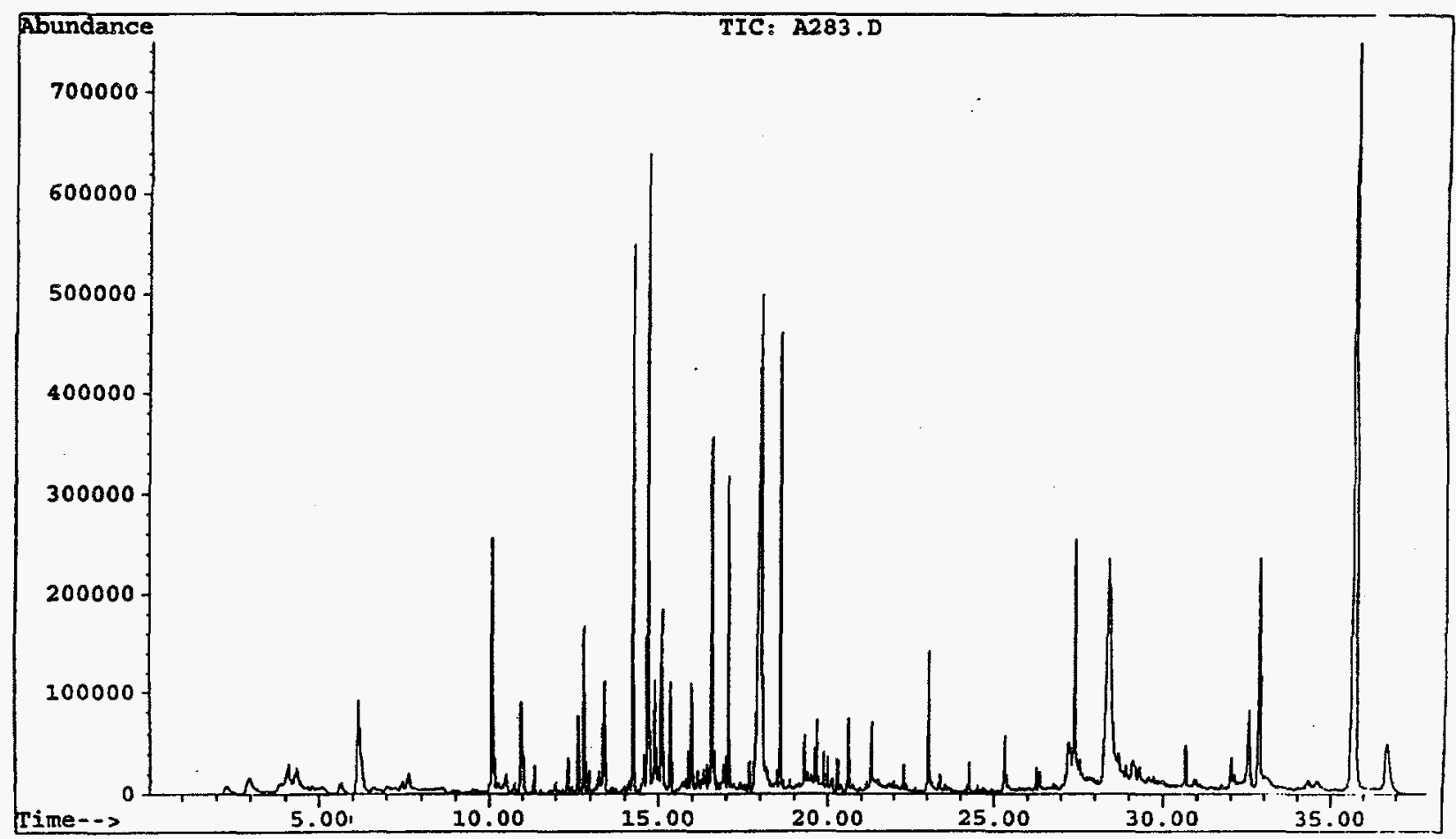




\section{Arr Sempling Deta Sheot}

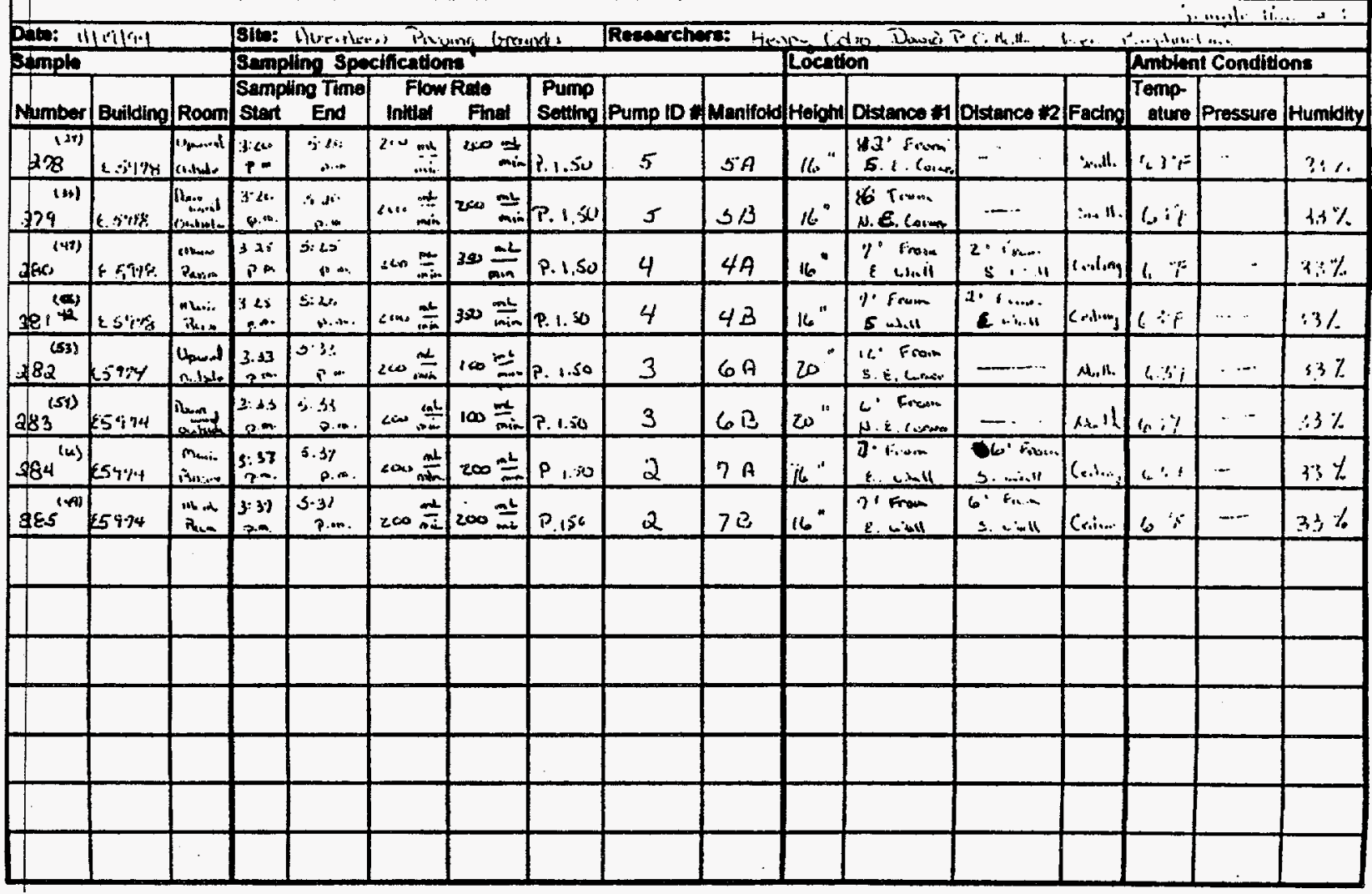

